\section{O "Schtetl": aspectos e valores}

\author{
Jacó Guinsburg
}

O século XIX encontrou, no mundo ídiche da Europa Oriental, o mais denso agrupamento judaico do globo e sem dúvida o mais característico do Velho Continente. De fato, enquanto seus irmãos do ocidente se jungiam, já em parte culturalmente assimilados, ao carro triunfal da revolução burguesa e sacrificavam na ara das igualdades civis e políticas a sua identidade grupal, o judeu do leste continuava recluso na noite medieval do gueto, integrado nas suas formas retrógradas de viver e pensar. Porem, como observou agudamente Heine - ele que foi o próprio símbolo do judeu ocidentalizado e já marginalizado - em $1822^{(1)}$, "apesar do bárbaro gorro de pele que cobre a sua cabeça, apesar das idéias ainda mais bárbaras que habitam este cérebro...", "...em seu isolamento, fez-se pleno e inteiro o seu caráter... o homem em seu interior não se transformou num composto qualquer de sentimentos quaisquer". Era essencialmente o judeu do schtetl (cidadezinha), com sua fisionomia inconfundível.

O schtetl, isto é cada uma das inúmeras aldeias e povoados que se espalhavam através, da Pale $^{(2)}$, abrigava uma comunidade segregada, mas não emparedada em certos bairros $^{(3)}$ dos grandes centros, como no oeste europeu. Localidade rural, ilhota quase exclusivamente judaica em meio ao mar eslavo, era a base de uma sociedade sui generis, misto de classe social, minoria nacional e congregação religiosa. Composta em sua esmagadora maioria de pequenos mercadores, artesãos, estalajadeiros, contratadores e arrendatários, situava-se, com respeito ao meio circundante, "entre o nobre e o aldeão"(4), e vinculava-se, interiormente, não só pelo tronco e pelas tradições de Israel, como por um passado local de vários séculos, por uma língua própria, uma cultura específica e a clara consciência de um destino comum.

Neste agrupamento, embora existissem ricos e pobres, privilégios e injustiças sociais, as desigualdades de classe eram relativamente pouco acentuadas e seus antagonismos quase só afloravam nas querelas congregacionais ou nos movimentos religiosos. Não porque reinasse uma ordem capaz de dirimir de algum modo tais diferenças e conflitos. Se a noção de Povo Eleito, de cujo favor todos, sem exceção, desfrutavam, e se as circunstâncias da Diáspora, que impunham a todos a mesma situação de fato, davam aos filhos de Israel a igualdade perante a Lei e determinavam a democracia no seio da Sinagoga, não é menos certo que o selo da fortuna, da linhagem (o requestado ihus), da posição e do saber concediam vantagens efetivas aos seus detentores.

Nos templos, centros da vida coletiva, a distribuição dos assentos, com maior ou menor proximidade da Arca, refletia uma graduação, uma hierarquia, em que os balebatim ("donos de casa", burgueses) e os talmid-hahamim ("versados na Torá", eruditos, intelectuais) ocupavam o cimo. Unidos por uma espécie de aliança, firmada sobretudo pelo matrimônic e baseada de um modo geral na troca do dinheiro pela estirpe ou pelo saber - visto que se tratava de uma sociedade centrada em valores que dependiam do conhecimento e da exegese dos Livros -, os dois grupos detinham em conjunto a direção política e espiritual da comunidade. Sob o seu ascendente, os artífices, carregado-

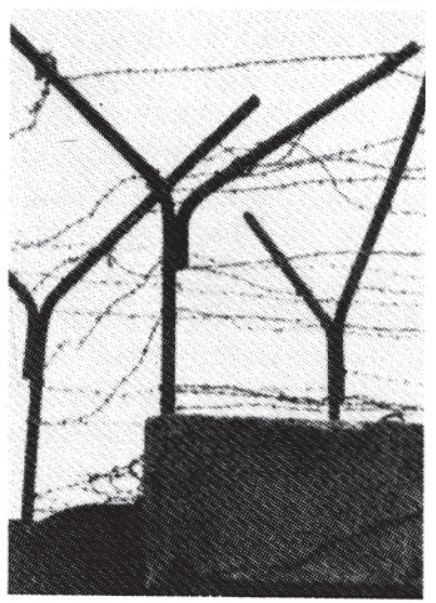

JACÓ GUINSBURG é professor de Teoria Teatro da ECA-USP, editor da Perspectiva e autor de, entre outros, Stanislávski e o teatro de arte de Moscou (Editora Perspectiva) e Leone de 'Sommi um judeu no teatro da Renascença (Editora Perspectiva).

1 Sobre a Polonia, nos Reisebilder.

2 Lit., o cercado. Denominaçắo do conjunto de distritos em que os judeus gozavam de permissáo de residencla no tempo do império tzarista.

3 A palavra gueto, que em geral os de signa, proviria, segundo uns, do he signa, proviria, segundo uns, do he segundo outros, do alemăo gitter (barrelra), do italiano borghetto (pequeno bairro) e gietto (fundiçăo de canhöes em Veneza, junto ao primitivo bairro judeul. A mesma noç大 de ver lsolado setor lsolado em meio a uma aglomeraçáo urbana subsiste nas denomina çoes de vicus Judeaorum, Judenstrasse, Judengasse, Judiaria, Juive rie e Carriera que os bairros judeus assumiram em diferentes épocas e palses europeus. (Ver The ghetto, Louls Wirth.)

4 Heine, op. cit.

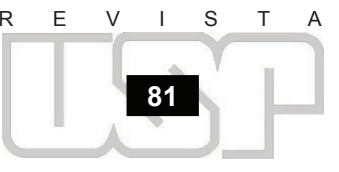


res, aguadeiros, bufarinheiros, cocheiros e a massa dos desprotegidos da sorte constituíam, na base, uma arraia miúda, sem a menor estruturação de classe. Pouco afeitos ao estudo da Lei, e muitas vezes analfabetos, viam-se relegados ao grau de fiéis de segunda categoria cuja voz quase não se fazia ouvir nos conselhos e concílios comunitários. Entretanto, tudo isso não bastava para criar fronteiras muito rígidas e contradições demasiado explosivas. Pois, de um lado, neste schtetl essencialmente pré-capitalista, nem 'as camadas superiores concentravam suficientes meios de produção nem as inferiores vendiam suficiente força de trabalho e, de outro, dadas as proibições econômicas e jurídicas que pesavam sobre os judeus e a instabilidade de sua posição no país, não havia raiz territorial e agrícola ou atividade militar e política que assegurasse privilégios duradouros e criasse coletivamente distinções intransponíveis. Ademais, sobrepairando a tudo, o pogrom e a perseguição comprimiam e acondicionavam as tendências díspares, descrevendo um círculo discriminador em torno de todos, lançando o ricaço e o pobretão no mesmo barco. Alienado, marginalizado e periodicamente brutalizado, este agrupamento encontrava no perigo externo um fator de trégua interna e, nesta eterna defensiva, cimentava os seus frágeis redutos, opondo-se em bloco ao mundo não-judeu, os goiim, que assumia o significado demoníaco da violência, do sacrilégio, da cega opressão, que consubstanciava a "ameaça do Punho contra a Palavra"(5).

Assim, rodeada de muralhas por dentro e por fora, inatingida ainda pelas forças desagregadoras dos novos tempos, a "cidadezinha" parecia dormitar à beira do tempo e da história, no aconchego de uma unidade quase primitiva. Pequeno-burguesa, com ritmo trôpego das vidas miúdas que se arrastam pelos velhos e batidos caminhos da província, entalada numa economia escassamente rendosa, sem qualquer vibração, o seu dia-a-dia era árduo e mesquinho. Mas, para além da mediocridade material, e dela separada por sacrossantas barreiras, achava-se o único "fim" que, aos olhos do judeu do schtetl, social e psicologicamente alheio ao utilitarismo ocidental, justificava "este" mundo: a esfera edênica da beatitude sabática, o "outro" mundo. Céu de sublimação, tecido com sonhos e anseios milenares, ofertava ele generosamente as suas certezas tanto ao erudito, que conhecia os mistérios da Torá e investigava os desígnios divinos, como ao humilde trabalhador, que mal sabia repetir um salmo e percorria apenas as estradas da prece sincera. Era aí, neste reino, que o mísero judeu do cotidiano, abandonando esta sua existência surrada e puída como o seu gabardo, trocava de "alma", se revestia dos paramentos da "infinita devoção", ingressava na santa congregação dos eleitos, colocava-se diretamente em face do Trono de Glória, colhendo sua luz com os olhos da fé.

Neste mundo "intoxicado de Deus" nada mais separava a criatura de seu criador. Desapareciam os limites entre o terreno e o celestial, a "infinita distância", de que falavam os teólogos, desfazia-se convertida em "infinita proximidade". O homem, pela operação interior que o engolfava em Deus e levava este da transcendência ritual à imanência mística, retornava ao seu "lugar", como no relato hassídico em que os discípulos perguntam ao rabi: "- Por que é que Deus é chamado makom, ou seja, lugar? Ele é certamente o lugar do universo, mas deveriam então chamá-lo assim e não apenas 'lugar'. O santo mestre responde: - O homem deve entrar em Deus, de modo que Ele possa envolvê-lo e tornar-se o seu lugar",(6).

Não se poderia pretender, é claro, que toda a vida religiosa da "cidadezinha" se desenrolasse ao nível do ato de fé pessoal, da experiência autêntica, que pressupõe esta vontade de fundir-se com a Divindade, de submergir nos abismos de Seu espaço. Ao contrário, boa parte dos fiéis, membros que eram de uma cidade e não de uma confraria mística ou ascética, apenas rendia aos céus o seu quinhão diário de cerimônias e práticas exangües, rotineiras, incrustando-se no ressequido receituário da casuística legalista e do dogmatismo religioso, contra os quais o hassidismo terçava lanças com e pelo fervor.

É certo, porém, que a religiosidade popular, fortemente marcada em seu conjunto pela devoção hassídica - em cuja ação eminentemente social os "místicos que atingiram seu objetivo espiritual... voltaram-se para o povo com o seu conhecimento místico e o seu cabalismo transformou-se em ética,"(7) - , se processava com a intensidade da vivência e era perpassada pela Presença viva e palpitante. Para o homem do schtetl, o espírito divino, a Schehina, através das fagulhas decaídas no ato da gênese, compartilhava do seu exílio, estava no mundo, era uma realidade existencial, que animava os seres e as coisas, não como uma força difusa num despersonalizado panteísmo, porém como um Tu onipresente, que o constituía em Eu e sobretudo em seu interlocutor. 


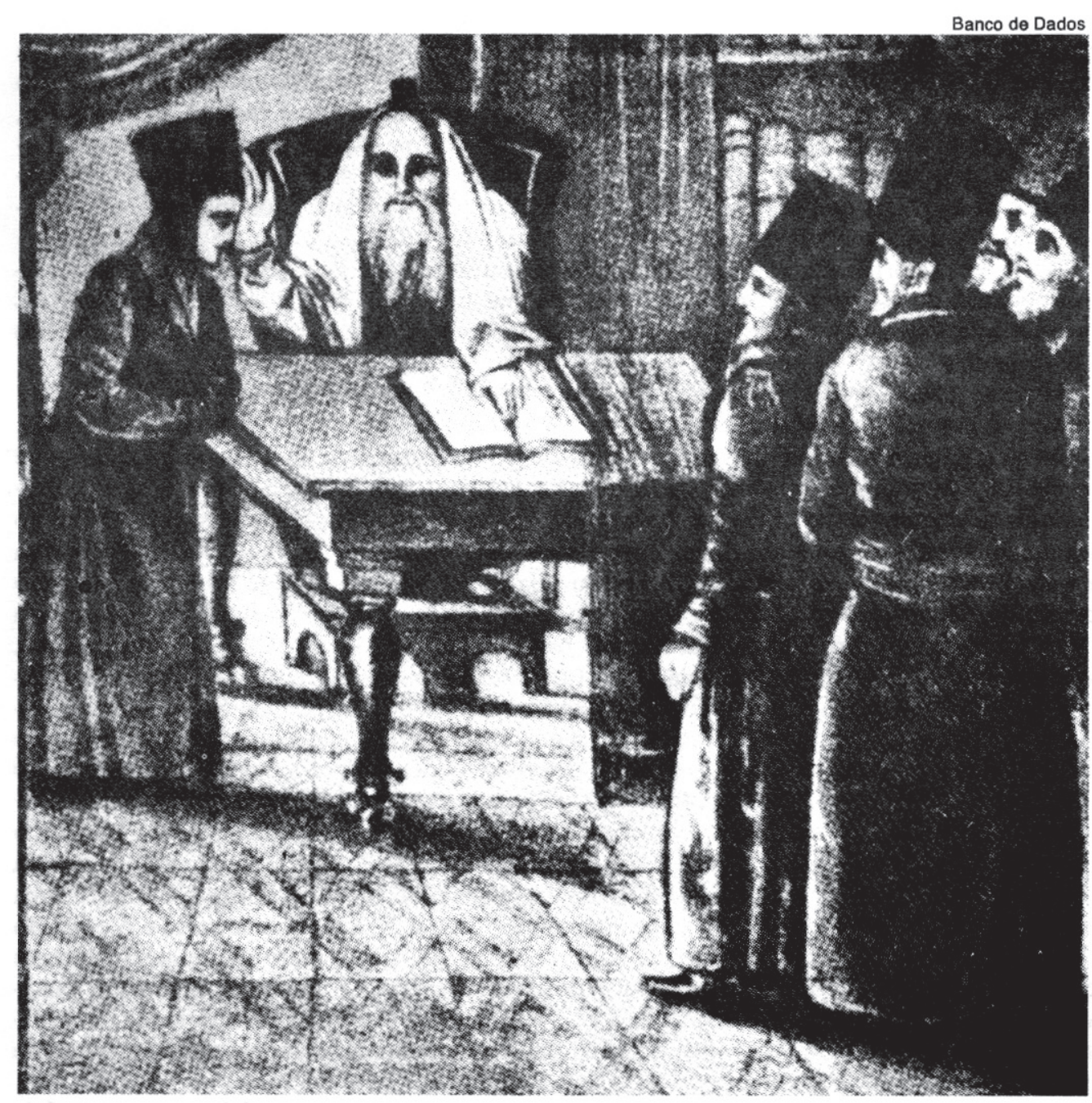

Assim, rodeada de muralha

por dentro e por fora,

inatingida ainda por

forças desagregadoras dos

novos, a "cidadezinha"

parecia dormitar à beira

do tempo e da história...
Com efeito, a sua relação característica com Deus - e que por certo se vinculava estreitamente com o próprio modo de ser dessa sociedade dominada por valores religiosos, manifestando-se em essência por meio deles, mas pobre, reduzida à humilde sinagoga de aldeia, sem maior arquitetura ou outras formas de plasticizar esteticamente $o$ "culto" - era a intimidade dialógica.

Todavia, se algumas individualidades excepcionais rabis e cabalistas estabeleciamna em termos que podiam implicar um EuTu transcendentes, protagonistas de um diálogo em que o Verbo se faz ação criadora, gênese, como o interpreta modernamente o existencialismo religioso de Buber, o povo o desenvolvia na linha menos ambiciosa, mais plebéia, do simples trato verbal, da conversa familiar, popularesca, de um Eu e um Tu que cavaqueiam com intimidade sobre as agruras da vida. $\mathrm{Na}$ verdade, o $\mathrm{Tu}$, no caso, convertia-se na possibilidade de tutear o Senhor Deus, quase na de lhe dar uma amistosa palmada no ombro e lhe dizer: "Eh, Paizinho, Tu me entendes".

Assim, esse divino interlocutor surgia como uma espécie de alter ego, um "outro eu" do judeu do schtetl. Partícipe de suas misérias e de sua Diáspora, que também o degradavam e alienavam, estava ao alcance de seu suspiro e de sua queixa, mesmo quando, no colóquio dos infortúnios, a reclamação dizia respeito a Ele próprio e envolvia a Sua ordem, como na famosa oração de Levi-Itzhak de Berdítchev, figura proeminente do hassidismo, que se dirigiu ao Todo-Poderoso com a seguinte demanda:

"Bom dia, a Ti, Senhor do Universo,/Eu, Levi-Itzhak, filho de Sara de Berdít-

O rabi Israel de Kozienic abençoa um menino

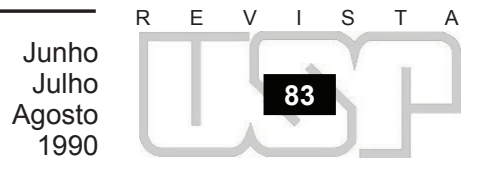


chev,/Vim a $\mathrm{Ti}$ com um pleito contra $\mathrm{Ti}, / \mathrm{Em}$ favor de 'Teu povo Israel./O que desejas de Teu povo Israel?/Por que afliges Teu povo Israel?/À menor coisa, dizes:/'Fala com os filhos de Israel', /À menor coisa, Te voltas para os filhos de I rael./À menor coisa, dizes:/‘Conta aos filhos de Israel’./Nosso Pai! Há tantas nações no mundo,/Persas, babilônios, edomitas,/Os russos, o que dizem eles?/Que o seu imperador é o imperador./Os alemães, o que dizem?/Que o seu império é o império./E os ingleses, o que dizem eles?/Que o seu império é o império./E eu, Levi-Itzhak, filho de Sara de Berdítchev, digo:/“Glorificado e santificado seja o Teu grande Nome!'/E eu, Levi-Itzhak, filho de Sara de Berdítchev, digo:/'Daqui não me moverei/Deste lugar não arredarei,/É preciso que isso tenha um fim,/O exílio tem que acabar!/Glorificado e santificado seja o Teu grande Nome!"

Já nesta prece, que data do fim do século XVIII, é possível captar certa recusa, um gesto de impaciência, em face da ordem de coisas configurada no decreto do exílio. Embora não ocorra ainda qualquer afrouxamento na religio, na ligação ou pacto em que se esteia a comunhão existente entre o povo eleito e a divindade que o elegeu, continuando a erguer-se intacta essa Cidade de Deus, essa Jerusalém quase intangível ao acontecer histórico, pode-se dizer, com Peretz em $O$ pássaro exótico, que algo começa a bater "no coração da pedra". De fato, a voz do devoto rabi, e que traduz um impulso profundo do próprio movimento hassídico, expressa-se aqui como uma "vontade", um "eu" pleno que, na p 'pria crista da fé e na da liberdade decorrente da "semelhança", se apresenta com "direitos" ao supremo Eu deste universo. A partir da relação dialógica, questiona-o, reivindica, exige dele, quer arrastá-lo ao "juízo" de Sua própria consciência, perante a qual contesta uma de suas "insondáveis" determinações. Em vez de se lhe submeter passivamente, de ir-lhe ortodoxamente à deriva, tenta suspender esse "destino", pôr-lhe cobro mediante uma iniciativa "fervorosa", que é por certo a de alguém dotado de "poder", com voz e força "comovedora" - como o beato hassídico imaginava o seu rabi - mas que é, não obstante, um "ato" humano, na medida mesma em que procura influir nos "altos mundos" e visa precisamente cortar o fio do drama escatológico de culpa e expiação que persegue o judeu através dos séculos e o exila do "século". Vozes secretas formam, pois, um coro invisível ao rasto desse gesto: carente em sua existência, alienada em sua subjetividade, reduzida a objeto de outrem, à passividade, a "vítima-testemunho" aspira a reintegrar-se no devir, na historicidade, a fazerse novamente sujeito de sua própria história e manifesta-o nessa asserção da vontade humana em face da imposição divina.

Na verdade, esse século XVIII tão decisivo para o Ocidente também representa importante marco na vida do schtetl. Se é difícil determinar até que ponto ele entra com seus ingredientes racionalistas e burgueses na obscura alquirnia social do gueto do oriente europeu, é certo que em seu transcurso não só amadurece, "nos recônditos do espírito judeu e no Santo dos Santos da doutrina mística da Cabala"(8), a crise que se produziria com o aparecimento da Hascalá do Iluminismo, como irrompe e se alastra, qual fogo de estio, o movimento hassídico. Última centelha religiosa do judaísmo tradicional, essa surpreendente pregação de Israel Baal Schem Tov, o Rabi do Bom Nome, constitui provavelmente, sob certos aspectos, a primeira fagulha deflagradora do judaísmo moderno. Com efeito, ao contrário do que preiendia a historiografia iluminista, com as notórias incompreensões de um Graetz, por exemplo, o hassidismo não foi apenas um ardor obscurantista de beatos ignorantes, explorados em sua crendice por curandeiros e taumaturgos. Tampouco é possível encará-lo, como desejou a escola positivista de Dubnov ou a do marxismo dogmático, tão-só como o protesto das massas asfixiadas pela ortodoxia rabínica e pela opressão econômica e política do meio gentílico, ou como uma sublimação e um ersatz psicológico da esperança escatológica, tão desastrosamente frustrada pelos falsos messias do século anterior. Ele foi tudo isso, e mais ainda.

Ao calor de seu "entusiasmo", "que trazia o céu para a terra e encarnava os mais altos mistérios em simples e às vezes grosseiros símbolos"(9), processou-se uma transmutação de valores e "fins" tradicionalmente constitutivos do judeu. Dentro dos quadros consagrados, dos "espaços" e "tempos" qualitativos, privilegiados, de um mito religioso, começou este pietismo a abolir as diferenças essenciais "entre espaços sagrados e profanos, entre tempos sagrados e profanos, entre ações sagradas e profanas, entre palavras sagradas e profanas"(10) e a refundir a visão consagrada do mundo e do homem. Iluminou-os de tal forma com a sua "euforia", com a sua exaltação da natureza com dádiva divina e da personalidade humana como individuação da essência energética e vital de Deus, que tornou "para o homem" um universo que era até então exclusi- 
vamente "para Deus": "Se eu amo o Senhor", diz o Baal Schem Tov, "que necessidade tenho eu de um mundo vindouro?"

Embora retivesse e até fortalecesse a fé no advento de um messias, o hassidismo desenterrou a redenção do fim dos tempos, para convertê-la em ato "aqui-agora". Pois o Ser Infinito, que é uma presença ubíqua, também habita a "impureza do cotidiano", e encontrá-lo aí, e ouvir "o seu cântico sem voz" em cada ato, em cada momento, em cada lugar, é o que "reúne" o homem à Divindade, à sua fonte primeira, e o resgata do exílio, da alienação, santificando-o neste mundo. Para isso, porém, ele não prescinde de um guia capaz de conduzi-lo da contaminação à pureza e de iniciá-lo na "via" pela qual a "força corruptora" se transmuda em impulso para a ação redentora: é o rabi. Dada a interação entre a esfera terrena e celeste, que é básica na crença hassídica, e cujo alicerce é a "simpatia do Todo" de que fala Cassirer, o santo mestre, com a sua individualidade depurada pelo exercício místico, exerce função-chave, intercomunicadora. Pela atuação mediadora e exemplar do tzadik, o "parteiro" da libertação interior do "discípulo", realiza-se a catarse das potências demoníacas, exorcizadas sobretudo no êxtase jubiloso. Mas a relação do fiel com este rabi não é formal e hierática, como o era "em princípio" a do rabino com a sua congregação. O laço é fortemente pessoal e afetivo, independendo da letra morta das prescrições livrescas. É a Torá viva, como Peretz a descreve em Entre duas montanhas: "E sobre a planície banhada de luz passeavam os grupos de hassidim. Seus gabardos de cetim, mesmo os de qualidade inferior, refulgiam como espelhos. Gabardos velhos e rotos e gabardos novos, todos refulgiam. E a luz que palpitava nas plantas desprendia-se delas para agarrar-se aos trajes brilhantes e festivos, bailando em redor dos hassidim com entusiasmo e amor... E todos os grupos de hassidim voltavam para o balcão do rabi os olhares ansiosos e maravilhados... E os olhares ansiosos, pude ver claramente, sorviam a luz do balcão e do rosto do rabi... E quanto mais luz absorviam, mais alto cantavam... Mais alto... Cada vez mais alto... Com crescente enlevo e beatitude..."

Ao contrário da outra, esta Torá não é feita de "dogmas de ferro, leis de cobre... para eruditos, para alguns privilegiados". Encontra-se ao alcance do "todo", do povo. Qualquer criatura, douta ou não, portanto o homem "simples", o "pobre de espírito", o "judeu do salmo", a quem a ortodoxia sonegava o "direito" tanto à terra como ao céu, está apta a conhecê-la, a participar da comunhão dos "eleitos", porque tal conhecimento não nasce do saber e do intelecto, porém da devoção e do sentimento.

Este democrático franqueamento da salvação, do reino do céu, pelo fervor do coração, pela alegria extática, deu nova "alma" ao judeu do schtetl. Assegurada a sua "projeção" no mundo ideal, sentiu-se ele mais seguro de sua "posição" no mundo real. Sua voz exultou no coro dos hassidim, com novo senso do valor de sua vida e de sua pessoa, pois, como edifica rabi Azriel, em $O$ dibuk "qualquer lugar onde o homem erga o seu olhar para o céu é um Santo dos Santos Todo ser criado por Deus à sua imagem é um Sumo Sacerdote... Toda palavra que o homem profere de coração é o Nome do Senhor". Realçado, santificado, o homem pela imanência divina no que ele tem de humano, torna-se como que um ponto e convergência do universo hassídico e o tzadikismo, ao enquadrá-lo sob este ângulo, desloca-se de certa maneira do teocêntrico para o antropocêntrico, aproximando a objetiva sócio-cultural do indivíduo e passando a focalizá-lo em primeiro plano. Assim, no plano histórico, não é só pela racional e laica "declaração de direitos" da Hascalá, a Ilustração judaica, mas também, e quiçá principalmente, pela exaltação emocional e religiosa, orgiasticamente celebrada no festim hassídico, que se manifesta "o ativo despertar das massas judias para uma nova compreensão dos esplendores da existência humana sobre a terra"(11), o que constitui, graças à sua ênfase na dignidade da pessoa, o primeiro passo para o reingresso do judeu, como homem, no tempo atual, na modernidade.

Mas o hassidismo é apenas um prenúncio deste retorno do além-túmulo. Com ele se enceta, ainda envolta no xale ritual, difusa na cantilena da prece, mesclada à celebração religiosa, a renovação do senso do "terreno" e da "realidade", a ressurreição do homem de "carne e osso" no judeu do schtetl. O momento crucial deste renascimento, em que a sua fisionomia começa de fato a emergir do "rebanho" de fiéis e a desenhar-se com autonomia em face da comunidade tradicional, é o da Hascalá.

Inspirado pelas idéias da Ilustração européia, promovido por comerciantes e intelectuais vinculados às atividades econômicas e às aspirações sociais da burguesia ascendente, este movimento, que se cristaliza na Alemanha a partir de meados do século XVIII, mas cujas raízes estão em toda a Diáspora ocidental, propugna por reformas ra- 
O Portal dos Judeus, em Lublin, Polónia

120 judeu que "pensa tornar-se um 'homem', nada mais do que um homem, um homem como todos os outros, Ingerindo todos os pensamentos do homem $\theta$ adquirindo um ponto de vista humano sobre o universo", que "se cultiva a fim de destruir em si judeu", em suma, que "procura "tazerse roconhecor" como homem pe flexoes sobre o racismo.

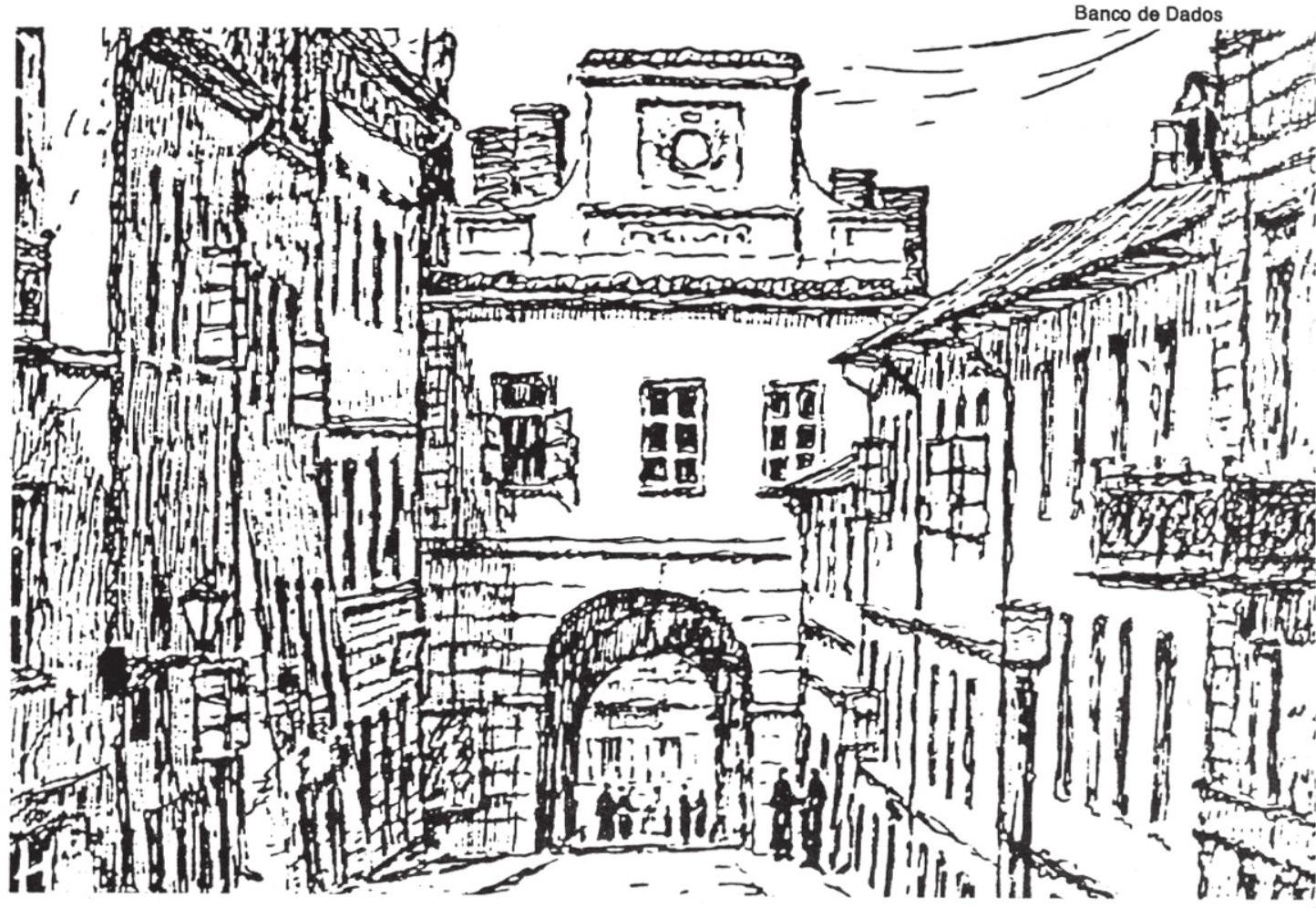

dicais na vida judaica. As luzes da Hascalá, que tem em Mendelsson a sua grande figura e em Natã, o Sábio, o seu modelo exemplar, pelo menos na primeira fase, apresentam-se em essência como um humanismo racionalista que pretende libertar o judeu das trevas da "superstição e do atraso" medievais e derrubar os muros do gueto, de sua segregação e exclusão do mundo. Elas se propõem a modernizar seus costumes e seu espírito, a ilustrá-lo, a secularizá-lo, a torná-lo "útil" à sociedade, enfim a "civilizá-lo", para que possa legitimamente rei-
Para o judeu ocidental a visão do "novo" homem é interna, orgânica, é uma representação de sua consciência coletiva e da dialética social desta. vindicar o seu lugar natural no concerto das consciências livres e contratantes do pacto social.

Trata-se, na verdade, de prepará-lo para a emancipação política e para a igualdade dos direitos civis, objetivo básico das forças propulsoras da Hascalá, que desejam ser admitidas de jure lá onde já participam de fato. Pará tanto, importa-lhes sobretudo transformar o "judeu" no "homem" ou no "cidadão", o que constitui a mola do esforço pedagógico desenvolvido por seu iluminismo.

No decurso dessa ação, e em virtude do próprio fim "real" visado e dos meios empregados para alcançá-lo, o judaŕsmo defrontou-se sem dúvida com grave crise. Pois, desfibrado em seu modo tradicional de existência pela renúncia à identidade nacionalreligiosa, viu-se reduzido a uma confissão reformada; a uma crença "mosaica" cujo cerne era a "legislação revelada dos mandamentos" (Mendelsson) e um deísmo esclarecido, condizente com o espírito bem pensante e admissível no Estado "moderno" (a Prússia, por exemplo...). A empresa racionalista implicou mesmo, em certos momentos de luta emancipadora, a aquisição do famoso bilhete heiniano de "ingresso na cultura européia" pelo batismo, isto $\epsilon$, não só na transmutação de valores, mas na perda da própria substância peculiar. Mas cumpre não exagerar as crfticas à Hascalá, como é de praxe desde Peretz Smolenskin e do surgimento das correntes que a superaram historicamente, buscando soluções mais orgânicas e positivas. Os efeitos negativos da campanha das Luzes, entre os quais está aquele que Sartre conceituou em nossos dias como o "judeu inautêntico"(12), não foram obra da Ilustração e da camada que ela representava, pois poderosos fatores externos, ligados ao mecanismo da sociedade burguesa no século

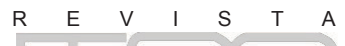


XIX contriburram igualmente, decompondo formas típicas, "autênticas", de vida e cultura e tornando, por exemplo, em certos parses, em dado momento, irresistíveis as tendências à assimilação. Se o movimento ilustrado teve o seu papel em tudo isso, é certo tambem que seu trabalho trouxe benefícios efetivos, "progressos", em todos os setores de sua atividade.

Com efeito, a sua empresa didática, na qual empenhou tanto zelo, resultou em autêntica renascença judaica. O pensamento sacudiu de si a poeira dos séculos de casuŕstica e teologia. As letras conheceram vigoroso surto: nasceu então a nova poesia e prosa de ficção hebraicas, para não falar da literatura idiche que apareceu formalmente em cena no período posterior da Hascalá, quando ela utiliza a língua do povo, o "jargão" f́diche, como instrumento da propaganda iluminista no âmbito do schtetl. O interesse pelas ciências naturais e pelos idiomas profanos do "pars" foi amplamente veiculado. Houve forte ação em favor do ensino humanístico e técnico, a fim de deslocar o judeu de suas ocupações habituais, tidas como parasitárias e cercadas de prevenções, e distribuŕ-lo nas profissōes "úteis".

Concomitantemente, conjugando e vitalizando esses esforços, o que refloresceu mesmo foi a confiança no ser humano, em sua qualidade racional e no poder criador dessa faculdade. Assim, a Hascalá se fez, no dizer de Halkin ${ }^{(13)}$, o arauto do primado da razão, da capacidade natural que tem o homem de pensar por conta própria, apresentando-a como o recurso mais eficaz de que o judeu pode dispor a fim de criar para si uma vida melhor neste mundo. Pregando-lhe a adoração da inteligência e da sabedoria, que são os deuses supremos da nova religião da razão, ela abre ao humilhado e ofendido, ao pária do gueto as promessas de um progresso humano infinito, as benesses do paraíso terrestre racionalista e, pela graça desse otimismo progressista, põe-lhe em mãos o fio de seu futuro, responsabilizando-o, enquanto indivíduo, não só por sua própria sorte, mas ainda pelo destino da coletividade.

No Oeste, embora percorrendo um caminho por vezes longo, tais reformas e os seus valores encontraram pronta a viva acolhida. A aculturação, para não abordar aqui os processos econômicos e sociais, vinha se realizando há muito na França, Holanda, Inglaterra, Alemanha, etc. A época moderna, com a Revolução Francesa, trouxe a possibilidade de formalizá-la, de legalizá-la por um estatuto político. (O qual, por sua vez, sem dúvida, acelerou o que já estava em curso.) Para o judeu ocidental a visão do "novo" homem é interna, orgânica, é uma representação de sua consciência coletiva e da dialética social desta.

Todavia, as Luzes tiveram de caminhar em sentido inverso ao da luz natural, do Ocidente para o Oriente. Pois no leste europeu é que se localizava a concentração maciça de judeus, o schtetl. E o que viram ar?, nos miseráveis aglomerados enterrados em um mundo feudal, onde o camponês era a besta de carga e o judeu o bode expiatório? $\mathrm{O}$ que distingüiram nesse meio turvo, retrógrado, povoado pelos fantasmas da crendice e do obscurantismo?

Certamente não foi o "homem inteiro" que o olhar genialmente penetrante de Heine percebeu, talvez por certa afinidade romântica com o medieval, mas sim "o bárbaro gorro de pele". Os maskilim, os agentes da Ilustração mendelssoniana, não podiam a princípio ver outra coisa senão aquilo que Salomon Maimon, este extraordinário aventureiro da inteligência, viu com respeito a si próprio: "Imaginai só um sujeito da Lituânia polonesa... com uma barba toleravelmente espessa, com roupas esfarrapadas e sujas, cuja linguagem é uma mistura de hebraico, f́diche, polonês e russo..."(14) Pois a Hascalá vinha de fora: examinava aquele universo de um lado paralisado na rigidez ritual dos 613 mandamentos do misnagd ("adversário", do hassidismo) e, de outro, convulsionado na orgia mística do entusiasmo do hassid a partir de um ponto de vista externo, objetivo; queria converter as tortuosidades e os escaninhos, os mistérios e os duendes, as maravilhas e os tetragramas, as rezas e os amuletos cabalísticos, a sem-razão em objeto da razão; propunha-se a escrutar suas sombras inescrutáveis à luz natural do entendimento claro e distinto, a criticar as suas "virtudes" com base em princípios abstratos. Ficou, pois, fora, pelo menos como visão. Não pôde entrar "realmente", pelo menos enquanto puro iluminismo.

De outra parte, era inevitável que a sua presença provocasse violenta reação do que era congênito, inerente ao schtetl: rabinismo e, mais ainda, hassidismo. Ambos se uniram para expulsar aquele olhar intruso, incômodo, que os constitura em objeto para outrem, causando-lhes mal-estar, não apenas por seus sarcasmos, pela sátira e paródia causticantes que lhes deformavam as feições vivas em contrafações caricatas, mecânicas

13 Op. ctt.

14 An autobiography.

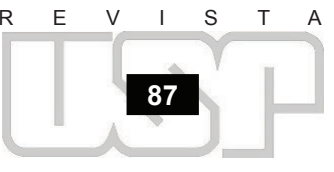




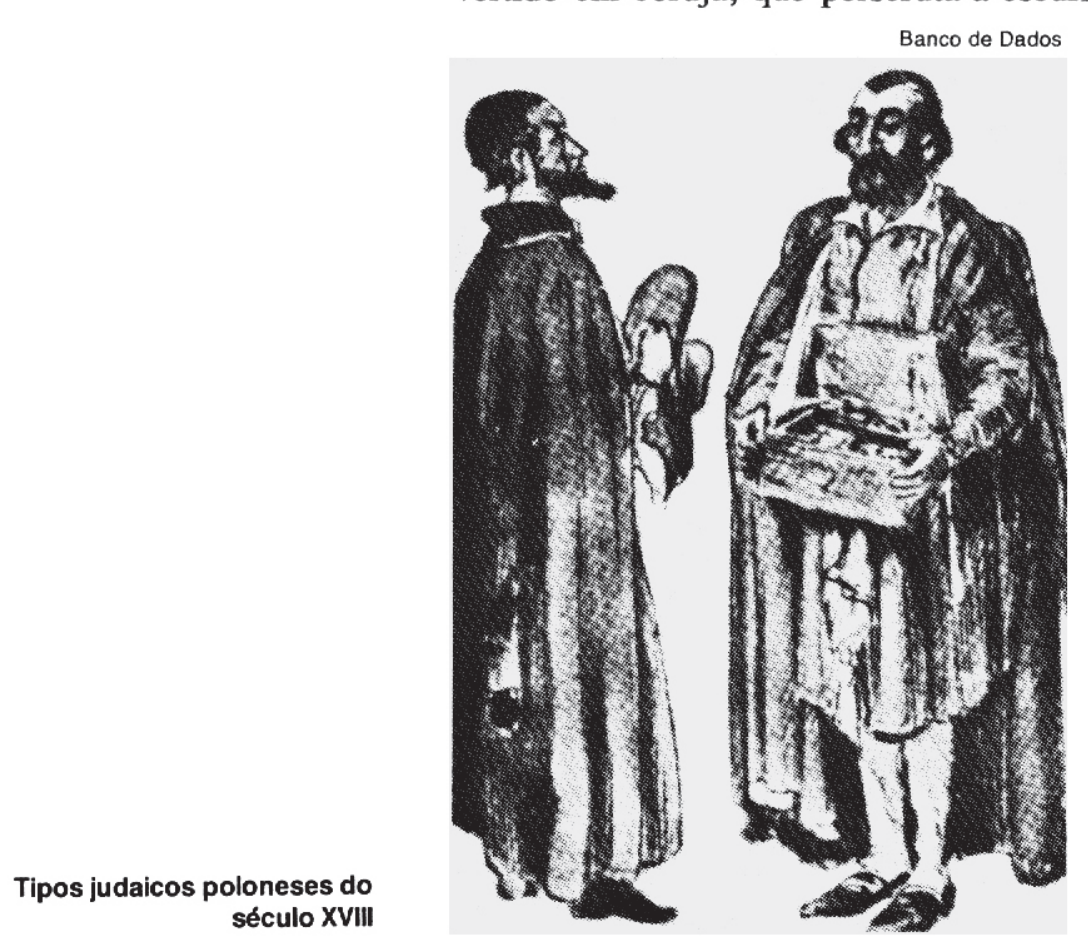

e que foi a arma predileta da polêmica racionalista, mas pelo espelho que lhes erguia, pela consciência crítica que assim suscitava. Nele, a imagem do schtetl se oferece cruelmente desvestida. Sem o encanto de sua beatitude popularesca, apresenta-se corroída, esquálida, degradada. Ela se faz Cabtzansk, a cidade dos pobretões de Mêndele, e o seu povo, "um bando de gente empunhando bordões, com sacolas às costas, como autênticos mendigos"(15). Mas particularmente impiedoso é o que se espelha ar do mundo religioso. O ridículo nada poupa, lança-lhe vitríolo até dissolvê-lo no burlesco e na estilização fabular-grotesca, como na Metamorfose da alma, onde "de um homem fazse um animal e de um animal de novo um homem". Cada metamorfose resulta num duplo quadro. $\mathrm{O}$ animal, em que o homem é metamorfoseado, é o símbolo e o reflexo do caráter humano. O hassid, que bebe cachaça feito água, é transformado em sapo; o sapo coaxante torna-se um hazan; o chantre, um lúcio; este peixe demuda-se em coletor de impostos, "que devora como o lúcio devora seus irmãos"; o contratador de taxas é convertido em coruja, que perscruta a escuridão; a coruja em cabalista; do cabalista surge uma toupeira; da toupeira, um coveiro; do coveiro, um cachorro; do cachorro, um fanático, "que acomete todo mundo como um cão danado"; o zelota dá origem a uma raposa; a alma da raposa transmigra para um rabi hassídico; o rabi transforma-se em burro; o burro em médico charlatão; o médico ignorante se converte em peru, e o peru, por sua vez, no arrogante com fumaças de nobreza, "que se enfuna qual um peru"(16).

Nesta tela típica da crítica ilustrada, que só conhece uma cor, o preto, e uma disposição, a negação, para descrever a vida judaica da época, a sociedade do schtetl fica portanto reduzida a um cadáver mal cheiroso, sobre o qual corveja toda sorte de aves de presa, de exploradores do povo, em especial "os vasos sagrados", rabinos, rabis e seus fâmulos. É claro que esta redução destrói realidades palpáveis daquela existência e valores então ainda plenamente subsistentes. Mas é claro também que ela põe a nu e salienta preocupações e problemas que começam a vincar, senão a encarquilhar, a face do schtetl.

De fato, não só a ortodoxia, de há muito ressecada e cujo rigorismo asfixiava cada vez mais o corpo social, como o próprio hassidismo haviałn perdido o seu viço, entrando em decadência. Juntamente com a "cidadezinha" que era o seu substrato, e à medida que a economia capitalista se infiltra na estrutura agrária e feudal do leste europeu, o tzadikismo se esvazia de seu conteúdo, sua euforia refrescante se apaga em práticas formais, sua mensagem popular e "democrática" torna-se quase inaudível sob o peso das dinastias de "santos homens" que se instauram em caráter hereditário e tiram partido, em proveito próprio, da crendice e do sofrimento das massas. Metamorfoseado numa espécie de clero, defende com unhas e dentes um tradicionalismo desvirtuado e, com ele, os seus privilégios. Mas a estrada de ferro, a imprensa, o telégrafo e a indústria rondam cada vaz mais de perto o seu reduto. Por dentro e por fora, as novas forças investem contra o isolamento, contra o gueto espiritual e material. O schtetl e o seu modo de vida estavam condenados: a História assomava à sua porta.

No entanto, cumpre reafirmar: foi a Hascalá o agente do diabo. No desejo de aparar a barba do judeu, de vestir-lhe uma fatiota "berlinense" e de pôr-lhe Rousseau debaixo do braço, fez-se seu tentador. Buscando-o nos interstícios da vida social e econômica, apresentou-lhe um espelho - convexo, sem dúvida... - e disse-lhe: "Veja como você é disforme. É preciso mudar". E quando o homem do schtetl atentou e "viu", o seu mundo estava desfeito. A Divina Presença o abandonara e, com ela, sua graça. Assim, depois de comer da Árvore do Conhecimento, ele praticou o ato reflexo e se viu na infinita solidão de um cotidiano hostil e brutal, submetido a um "processo" absurdo, kafkiano. É verdade que algum tempo depois o espelho mudou... 